\title{
メンタル・ローテーション・テストの誤答生成過程の分析 (3)
}

椎名久美子

独立行政法人大学入試センター 研究開発部

要旨 :メンタル・ローテーション・テスト（MRT）の被験者ごとの誤答原因を推定する手がかりを探 るために, RSP 版 MRT で記録された解答過程データから算出した指標一各選択肢の判断消費時間が 誤判断消費時間に占める割合一と解答方略の対応について分析した。本稿では，誤答の多い被験者が 苦手とする鏡像問題の 1 つである問題 14 に着目した。見かけ上は同じ選択肢の判断ミスによって誤 答に至った被験者の中には，各選択肢の判断消費時間が誤判断消費時間に占める割合に偏りがみられ る者とみられない者がいた，偏りがみられる被験者たちの解答過程シークエンス図には，図形の部分 的な特徵に着目して解いていくという共通点がみられた。 また，解答に要した時間や得点が大きく異 なる被験者でも，各選択肢の判断消費時間が誤判断消費時間に占める割合が類似している者は，解答 方略が似ていることも示された. 今後, 問題 14 以外の鏡像問題についても, 解答過程データから算 出した指標と解答方略の対応についての分析を進めることで, 各被験者の各問題の誤答原因を特定す る手がかりが得られると思われる.

キーワード : 空間認識，教育評価

\section{1. はじめに}

学生の空間認識力を評価する際に, Vandenberg と Kuse [1]が設計したメンタル・ローテーション・ テスト（以後，MRT と呼ぶ）が広く用いられてき た. MRT は, 基淮図形と同じ立体を 4 つの選択肢 図形の中から 2 つ選ぶ問題 20 問で構成されている (40 点満点).

Shiina et al.[2]は，パソコン上でMRTを実施す るソフトウェア (Recording-Solving-Process Version of the MRT，以後 RSP 版 MRT と呼ぶ）を 開発して, 被験者の MRT 解答過程データをネット ワーク経由で記録できるようにした. RSP-MRT で は，被験者のマウス操作によって 4 つ選択肢のう ちの 1 つだけを提示させる点が, Vandenberg らに よる MRT と異なっている. また, RSP版 MRT で は「正確さを失わない程度で出来るだけ早く」解答 するよう教示はするものの，制限時間を設けずに， 原則として全問 (20 問) を解かせる. 各被験者の解 答過程データとして, 各選択肢がいつどのような順 で提示されたか，いつどの選択肢を正答として選ん

干153-8501 目黒区駒場 2-19-23

\section{だか，等が記録される.}

Shiina[3]および椎名[4]は，RSP 版 MRT で収集 した解答過程データから，どの選択肢に関する誤判 断に時間をかけたのかを示す指標を算出し, MRT の誤答原因を探る手がかりになる可能性を示した. 指標に反映されている解答方略が明らかになれば, 各被験者の誤答原因を診断できる可能性がある. 本 稿では, 指標と, 解答過程のシークエンスの示され た解答方略との対応について考察する.

\section{2. 分析対象データ}

分析対象は, 2000 年 1 月から 2003 年 7 月にかけ て, 米国の大学[2]と日本の大学[3][4]でRSP版MRT を実施して得た 90 名分の解答過程データである.

表 1 に，それぞれの実施集団における制限あり得 点と制限なし得点の平均値等を示す. 制限あり得点 は, 各パート（前半 10 問と後半 10 問）を 3 分間の 制限時間で実施した場合の得点を解答過程データか ら算出した得点を指し，紙筆版でMRT を実施した 際の得点に相当する. 制限なし得点は，解答した問 題すべてを採点対象として算出した得点を指すもの とする. 制限あり得点, 制限なし得点共に, 米国の 大学生と日本の大学生の平均值には有意な差がみら 
れる(それぞれ, p<0.001, p<0.05). 米国の大学 生は 35 名中 29 名が男子であるのに対して[2], 日本 の大学生は全員が女子であり [3][4], 得点の平均值の 差には，実施国による違いと性差による違いの両方 が含まれている.

表 $1:$ 制限あり得点と制限なし得点の平均值

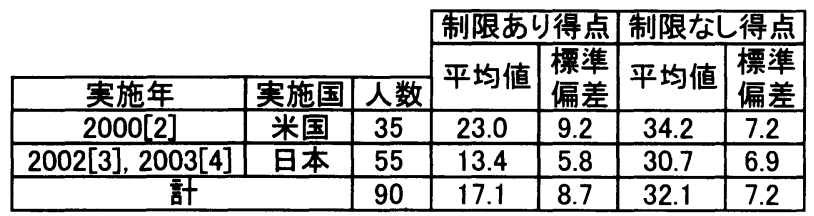

図 1 に，制限あり得点と制限なし得点の散布図を 示す. で示した米国の大学生の得点は, ○で示し た日本の大学生より高得点側に分布する傾向が見ら れる.

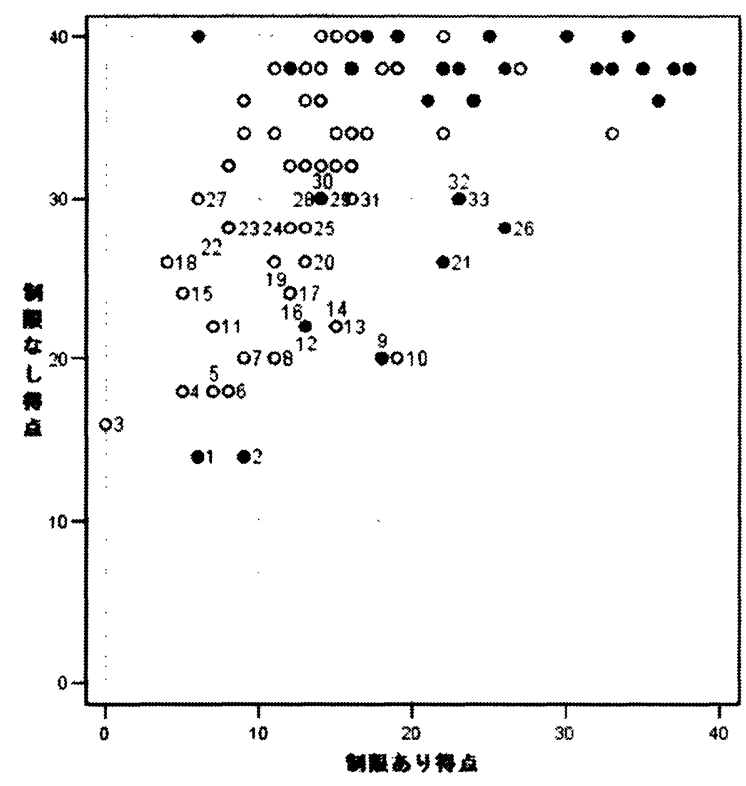

図 $1:$ 制限あり得点と制限なし得点の散布図 $（ \mathrm{n}=90 ） （$ : 米国の大学生, $\bigcirc$ : 日本の大学生) 点に添えられた番号は, 被験者番号.

MRT は，立方体から構成された図形の異同判断 の課題である. 椎名ら[5]は，着手した問題について の正答率は高いこと，多くの被験者が全問を解き終 わらないうちに制限時間に至ることを示し, MRT が Speeded Test であることを示唆している. RSP-MRTでは, 解答時間が十分に与えられており， 90 名中 87 名が全問を解き終わっている. よって, 制限なし得点が低い被験者は，問題に着手しても正
答にたどりつけなかった問題が多い被験者というこ とになる.

本稿では, 誤答が多い被験者として, 制限なし得 点が 30 点以下の被験者に着目する. 90 名中 33 名 が, 制限なし得点が 30 点以下の被験者であり, 図 1 で被験者番号を添えて示されている.被験者番号は, 制限なし得点が低いほうから順番にふってあるが， 同点の被験者もいる. 33 名の制限あり得点は，0点 から 26 点までの広範囲に分布している.

\section{3. 分析結果及び考察}

\section{1 鏡像問題と異物問題の得点}

表 2 は，制限なし得点を，鏡像問題で得た得点と 異物問題で得た得点に分けて，制限なし得点の範囲 別に平均值を算出したものである．鏡像問題とは， 誤選択肢図形と基準図形が鏡像関係にある問題であ り，それ以外が異物問題である. RSP版 MRT も才 リジナルの MRT と同様に, 鏡像問題と異物問題 10 問ずつで構成されている. 制限なし得点が 31 点以 上の被験者群では，2種類の問題の得点の平均值に 有意差はみられないが，制限なし得点が 30 点以下 の被験者群では，両者に有意差がみられる.

表 $2:$ 鏡像問題得点と異物問題得点の平均值

\begin{tabular}{|l|r|r|r|r|r|r|}
\hline $\begin{array}{l}\text { 制限なし得点 } \\
\text { の範围 }\end{array}$ & 人数 & \multicolumn{2}{|c|}{ 鏡像問題 } & \multicolumn{2}{|c|}{ 異物問題 } & \multirow{2}{*}{ 平均値の差 } \\
\cline { 3 - 6 } 31点以上 & 57 & 18.3 & 1.9 & 18.4 & 1.7 & 0.1 \\
\hline 30点以下 & 33 & 10.2 & 3.7 & 13.8 & 3.6 & $3.5(* * *)$ \\
\hline
\end{tabular}

椎名ら[5]は，オリジナルのMRTにおいて，低得 点者グループでは，鏡像問題の平均点が異物問題の 平均点よりも低い傾向がみられると報告している. 椎名ら[5]は，図形の部分的な特徵抽出などの心的回 転以外の方略を用いた場合，異物問題では正答可能 だが鏡像問題では誤答に至ることから，低得点者は 心的回転以外の解答方略を用いる傾向が強いと考察 している.

表 2 で示したように, 制限なし得点に関して, 30 点以下の被験者群では, 鏡像問題の平均点が高いこ とから，これらの被験者の鏡像問題の誤答には，心 的回転以外の方略を用いることが原因で生成される ものが多く含まれると予想される. 


\section{2 無提示時間を基準とした解答過程データの精 選}

各被験者の各問題の解答過程データには, どの選 択肢がいつ提示されたか，どの選択肢をいつ正答と して選んだか，いつ正答を取り消したか，等が記録 される.しかし，各問題で被験者が解答を開始した 後でも, どの選択肢図形も提示されない時間が記録 されている場合がある．複数の選択肢の間をマウス が移動する際に，そのような時間が生じる可能性も あるが, 1 問の中でどの選択肢図形も提示されない 時間があまりに長い時間生じるのは不自然であり，

RSP版 MRT のソフトウエアのバグとも考えられる.

図 2 は, 制限なし得点 30 点以下の 33 名の被験者 が解答したすべての問題（649 問）ごとに，どの選 択肢も提示されていない時間の合計（以後，無提示 時間と呼ぶ）を算出して，その分布を示したもので ある. 649 問のうち, 258 問 (39.8\%) が 1 秒末満, 216 問（33.3\%）が 1 秒以上 2 秒未満である. 両者 を合わせると全体の約 4 分の 3 となるので, これら だけでも, 分析の対象としては十分な数と思われる. よって，無提示時間 2 秒未満の解答過程データを正 常とみなして以降の分析対象とする.

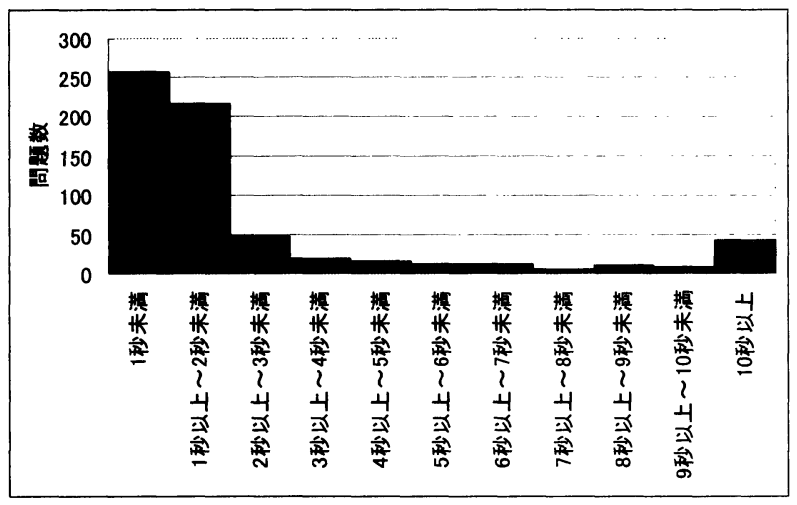

図 2 : 各問題の無提示時間の分布

\section{3 各選択肢の誤判断消費時間の割合}

RSP 版 MRT では, 基準図形といずれか 1 つの選 択肢を同時に提示させて，基準図形と同じ立体か異 なる立体かを判断する. 各問題を構成する 4 つの選 択肢すべてについての異同判断が正しければその問

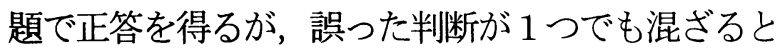
誤答を生じる.

解答過程データから，各問題において各選択肢が
提示された時間の合計を算出し，各選択肢の異同判 断に消費した時間（各選択肢の判断消費時間）とみ なすことにする. 各問題において, 誤った異同判断 が生じた選択肢の判断消費時間の合計を「誤判断消 費時間」と定義し，その中で，誤判断が生じた各選 択肢の判断消費時間が占める割合を算出する.

\subsection{1 問題 14 の選択肢 3 と 4 の誤判断に反映され た解答方略}

鏡像問題 10 問の中でも, 問題 9 と問題 10 は, 図 形の一部が他の部分を遮蔽しているために形状把握 が難しい選択肢を含んでいるが[3]，問題 14 は形状 把握が特に困難な選択肢を含まないという意味では， 普通の鏡像問題である.

問題 14 では 33 名中 16 名が誤答したが，そのう ち無提示時間 2 秒未満の者は 11 名である. 図 3 は, 問題 14 について，誤判断が生じた各選択肢の判断 消費時間が誤判断消費時間全体に占める割合を，正 常な誤答データとみなす 11 名について図示したも のである.

11 名のうち，3 名（被験者 $5,6,30$ ）が選択肢 3 と 4 で誤判断をしているが, 被験者 6 と 30 は, 選択肢 4 の誤判断の割合が非常に低いのに対して, 被験者 5 は，選択肢 3 と 4 の判断消費時間の割合は 約 $50 \%$ ずつになっている.

被験者 5，6，30 の制限なし得点は，それぞれ， 18 点, 18 点, 30 点である. 被験者 5 と 6 は, 制限 なし得点も誤判断をした選択肢も同じだが，誤判断 消費時間の割合は異なる傾向を示している.

また，被験者 6 と 30 は，制限なし得点は大きく 異なるが, 誤判断をした選択肢は同じで, 誤判断消 費時間の割合は類似の傾向を示している.

図 4〜図 6 は，それぞれ被験者 6，30，5 の問題 14 の解答過程データを図示したもの（以後, 解答過 程シークエンス図と呼ぶ) である。縌軸は解答開始 からの経過時間を示す．横軸に番号で示した選択肢 図形が表示されていた時間が実線で示してある.（） で番号が囲まれた選択肢が，正解である。は，被 験者が正答として選んだ選択肢とその時刻を示寸。 ○は，正答を取り消したこと及びその時刻を示す.

図 4 に示すように，被験者 6 は，選択肢 1 ～3を 順次 7〜8 秒ずつ提示させていずれも正答としてい 
る. その後, 選択肢 4 を短い間提示させた後で選択 肢 2 に戻りしばらく提示させてから, 選択肢 2 の正 答を取り消して解答を終了したことが示されている.

図 5 に示された被験者 30 は, 選択肢 $1 \sim 2$ を順 次提示させていずれも正答とした後, 29 秒くらいま での間，選択肢 3 と 4 を順次提示させている．その 後, 再度選択肢 1 と 2 を提示させて, 選択肢 2 の正 答を取り消しているが (47.5 秒付近), その直後に 選択肢 3 を正答として，解答を終了している.

被験者 6 と 30 が問題 14 の解答にかけた時間は, それぞれ, 36.2 秒と 50.0 秒でかなり異なるが, 途 中まではどの選択肢も正答としている点や，一旦戻 って正答を取り消すことで正答選択肢の数が $2 つ に$ なったら,その後はあまり時間をかけずに解答を終 わりにしている点などの, 解答過程シークエンス図 の特徴は類似している.

それに対して, 図6に示した被験者 5 は，すべて の選択肢を順番に提示させて, 一通り見た後は, 前 の選択肢を再ひ提示することなく解答を終了させて おり，2つめの正答として選択肢 3 の判断を終えた 後も，選択肢 4 を 6.5 秒ほど提示させている. これ は, 被験者 6 や 30 とは異なる特徴である.

図 7 に問題 14 を示す. 問題 14 では, 基準図形と 選択肢は，すべて上部と下部の腕状部分が垂直関係 という特徴を持っており，この特徽に着目して異同 判断をしようとすると, どの選択肢も正答に思える. 被験者 6 や 30 が提示させていく選択肢をすべて正
答としていくシークエンスには，図形の上部と下部 の特徵に着目する方略が反映されていると思われる. 被験者 6 も 30 も, その方略では正答が 3 つ上上 になってしまうことに気づいたため, 再び選択肢 2 に時間をかけて再吟味して正答を取り消したと思わ れる.が，選択肢 4 の再吟味はほとんどせずに，誤 った異同判断のままで解答を終了している.

選択肢 4 の判断消費時間が誤判断消費時間全体に 占める割合が非常に低くなっているのは，選択肢 4 の再吟味をしなかったことが反映されているが，そ れは図形の部分的な特徵に着目するという方略を用 いたことに起因している. よって, 被験者 6 と 30 の両者における選択肢 4 の判断消費時間の割合の低 さには，両者が共通で用いた解答方略が間接的に反 映されていると考えられる.

\section{3.2 問題 14 の選択肢 2 と 4 の誤判断に反映され た解答方略}

問題 14 では, 正常な誤答データとみなす 11 名の うち 3 名（被験者 $1 ， 7 ， 28 ）$ が選択肢 2 と 4 で誤 判断をしている. 同じ選択肢で誤判断をしているこ れらの3 名のうち, 被験者 7 ではそれぞれの誤判断 消費時間の割合に大きな偏りはみられないが，被験 者 28 は選択肢 4 の誤判断消費時間の割合が非常に 低く，被験者 1 は選択肢 1 の誤判断消費時間の割合 が非常に低い.

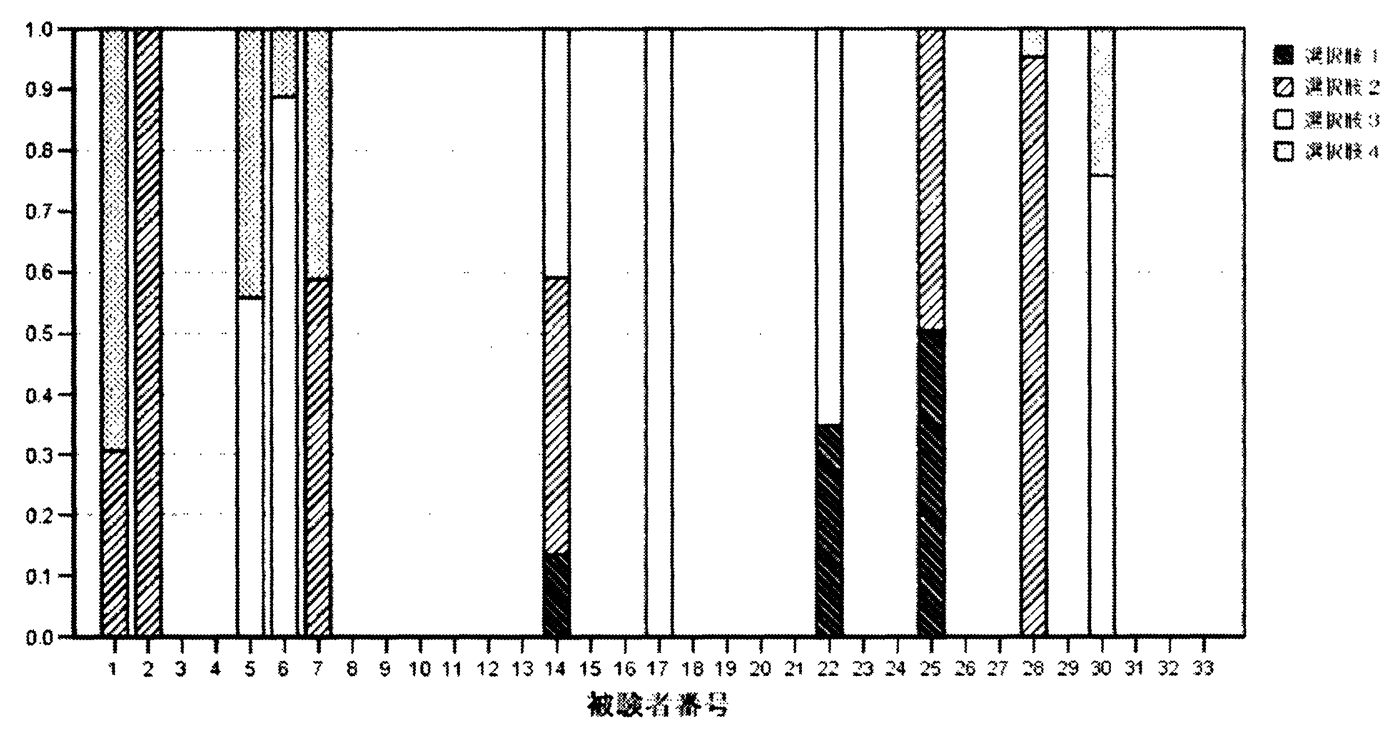

図 3 : 誤判断が生じた各選択肢の判断消費時間が誤判断消費時間全体に占める割合（問題 14） 


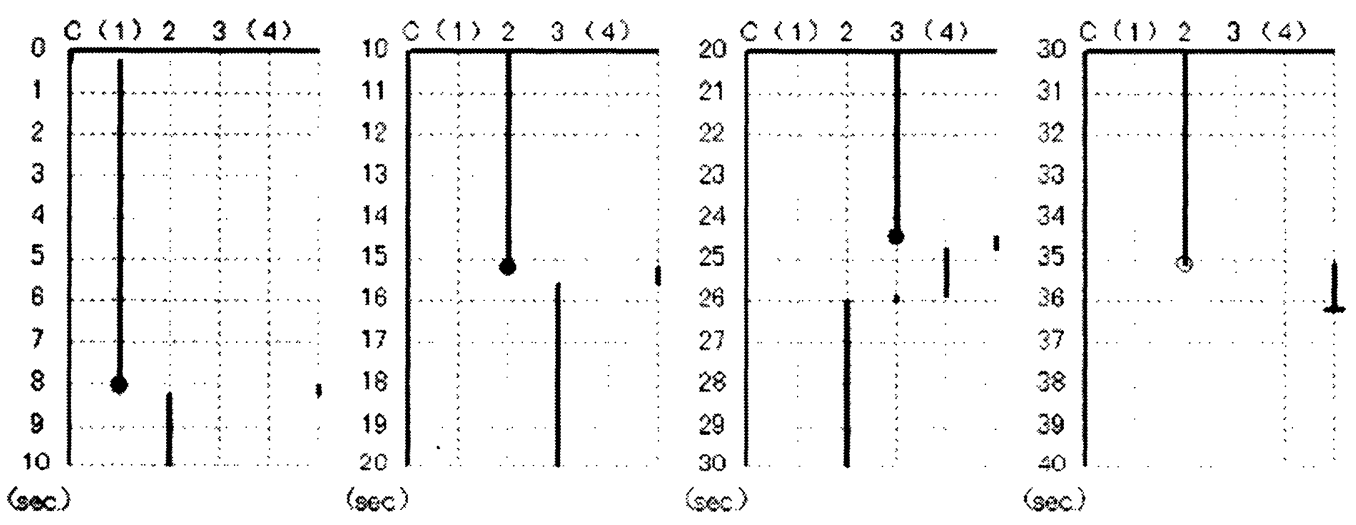

図 4 : 被験者 6 の問題 14 の解答過程シークエンス図（横軸：提示図形，縦軸 : 時間）

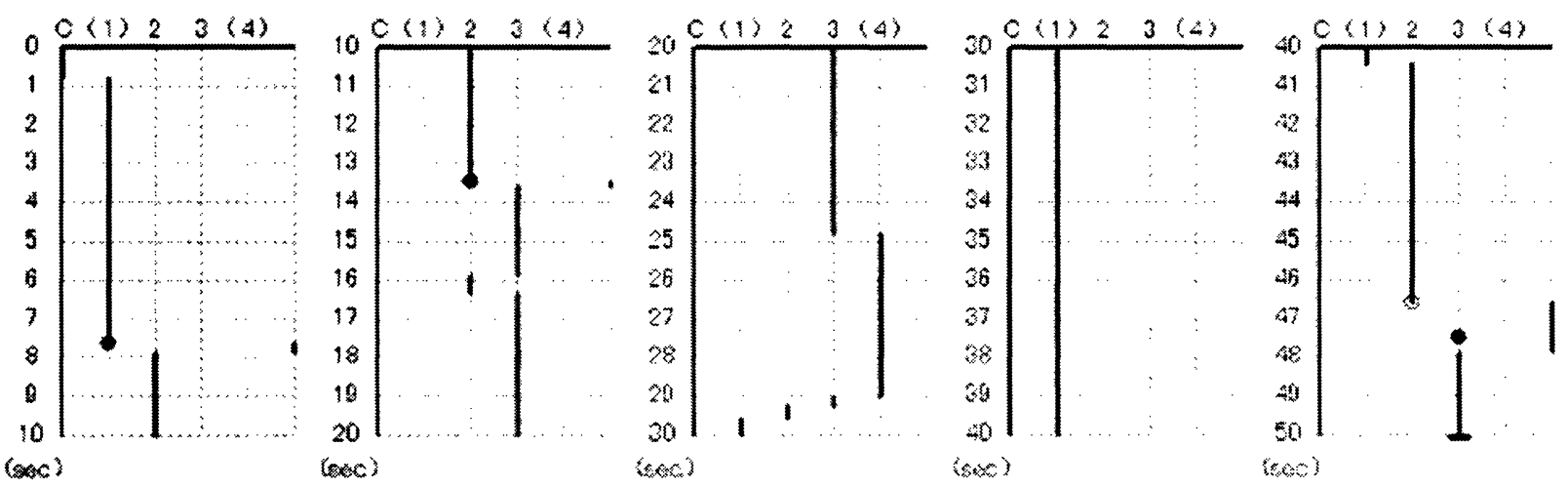

図 5 : 被験者 30 の問題 14 の解答過程シークエンス図（横軸 : 提示図形, 縦軸 : 時間)
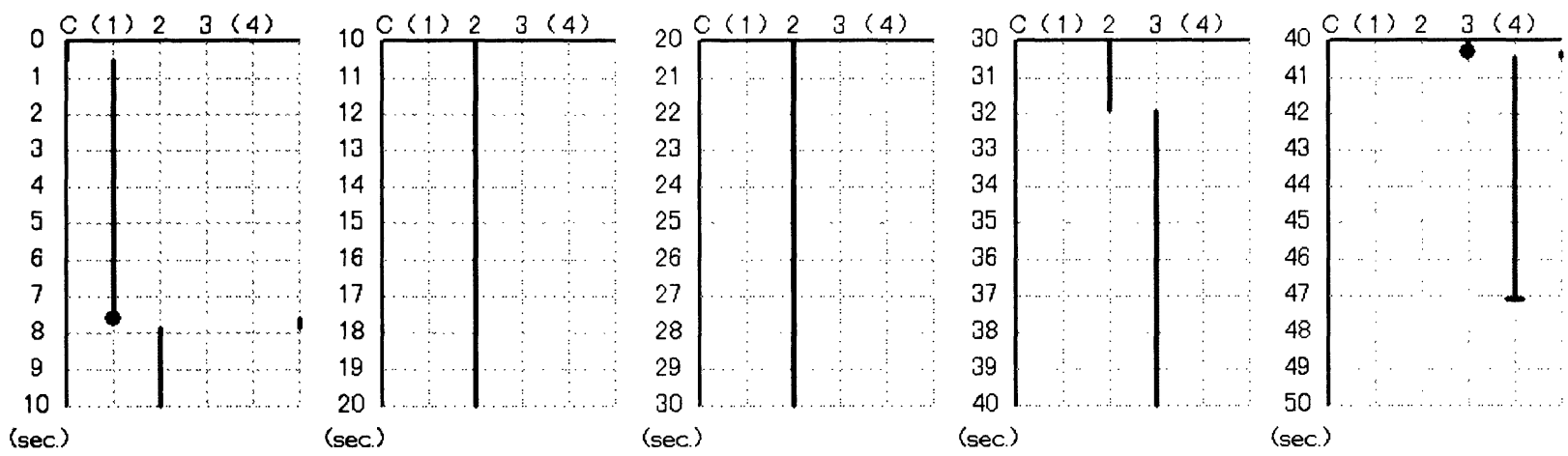

図 6 : 被験者 5 の問題 14 の解答過程シークエンス図（横軸 : 提示図形, 縦軸 : 時間)

14.
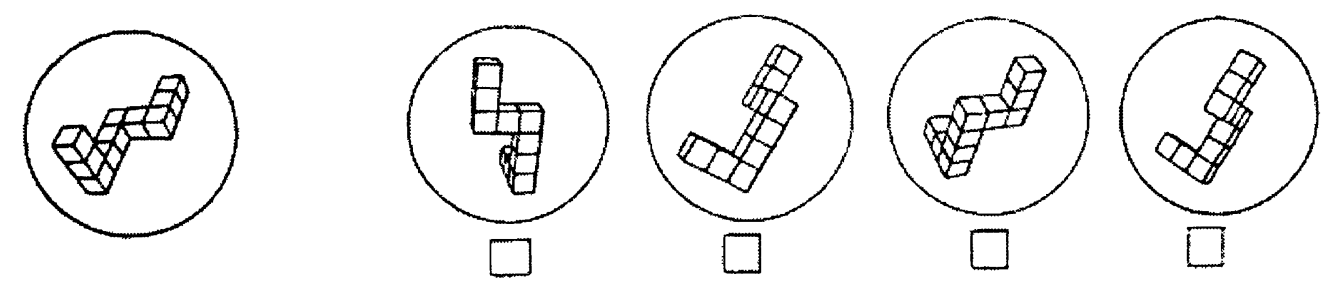

図 7 : 問題 14（Vadenberg \& Kuse[1]のMRTより） 
被験者 1，7，28 の制限なし得点は，それぞれ， 14 点, 20 点, 30 点である. 被験者 1 と 28 は, 制 限なし得点は大きく異なるが, 誤判断をした選択肢 は同じで，誤判断消費時間の割合に偏りがみられる という点では類似の傾向を示している.

解答過程シークエンス図は，被験者 1 も 28 も， 選択肢を順に提示させていって，選択肢 1 と 2 の両 方を順に正答としている点で，共通の特徴を示して いる. 被験者 7 の解答過程シークエンス図には，そ のような傾向はみられない.

以上より，選択肢 2 と 4 の誤判断においても，選 択肢の判断消費時間が誤判断消費時間全体に占める 割合に偏りが見られる被験者 2 名は，図形の部分的 な特徴に着目するという共通の方略を用いているこ とが示された．また，選択肢の判断消費時間が誤判 断消費時間全体に占める割合で異なった傾向を示寸 被験者では，異なる解答方略を用いていることも示 唆された.

\section{4. おわりに}

本稿では，メンタル・ローテーション・テストの 被験者ごとの䛊答原因を推定する手がかりを探るた めに, RSP版 MRT で記録された解答過程データか ら算出した指標がどのような解答方略を反映してい るかを，鏡像問題の 1 つである問題 14 に着目して 分析した.

見かけ上は同じ選択肢の判断ミスによって誤答に 至った被験者の中には，各選択肢の判断消費時間が 誤判断消費時間に占める割合に偏りがみられる者と みられない者がいた．偏りがみられる被験者たちの 解答過程シークエンス図には, 図形の部分的な特徵 に着目して解いていくという共通点がみられた。 ま た, 解答に要した時間や制限なし得点が大きく異な る被験者でも，各選択肢の判断消費時間が誤判断消 費時間に占める割合が類似している者は，解答方略
が似ていることも示された.

今後, 問題 14 以外の鏡像問題についても, RSP 版 MRT で得た解答過程データから算出した指標之 解答方略の対応についての分析を進めることで，各 被験者の各問題の誤答原因を特定する手がかりが得 られると思われる。

\section{謝辞}

本研究は, 平成 $14 \sim 16$ 年度科学研究費補助金 (若 手研究(B), 課題番号 20280539）の助成を得て実施 された。

\section{参考文献}

[1] Vandenberg, S. G. and Kuse, A. R., "Mental Rotations, a Group Test of Three-dimensional Spatial Visualization", Perceptual and Motor Skills 47(1978), pp. 599-604.

[2] Shiina, K., Short, D. R., Miller, C. L. and Suzuki, K., "Development of Software to Record Solving Process of a Mental Rotations Test", Journal for Geometry and Graphics 5 (2001), pp. 193-202.

[3] Shiina, K., "Analysis of Time-Sequence Data for the Solving Process of a Mental Rotations Test", Proc. 6th China-Japan Joint Conference on Graphics Education, Xian (2003), pp. 213-218.

[4] 椎名久美子, "メンタル・ローテーション・テス 卜の誤答生成過程の分析(2)"，日本図学会 2003 年度本部例会学術講演論文集 pp. 47-52.

[5] 椎名久美子・鈴木賢次郎, "メンタル・ローテー ション・テストの問題解決過程に関する考察一ヘ 一パーテストの誤答分析を通して一", 図学研究 31(4) (1997), pp. 3-10. 